\title{
ANALISIS POTENSIAL PEMANFAATAN ENERGI SURYA PADA KAPAL IKAN DI PANTAI SELATAN PULAU JAWA SEBAGAI SUMBER ENERGI
}

\author{
The Potential Analysis of Solar Energy Utilization on Fishing Vessel in South Java Island \\ as a Source af Energy \\ Oleh: \\ Shanty Manullang1, M. Alfath Eneste', Ayom Buwono²
}

${ }^{1}$ Fakultas Teknologi Kelautan, Teknik Perkapalan, Universitas Darma Persada, Indonesia

2 Fakultas Teknologi Kelautan, Teknik Sistem Perkapalan, Universitas Darma Persada, Indonesia

*Korespondensi: shanty_manullang@ftk.unsada.ac.id

\begin{abstract}
One of the efforts to overcome energy crisis is to reduce dependence on fossil energy sources by utilizing alternative energy sources, one of which is solar energy. In Indonesia, efforts to utilize solar energy have the advantage that energy is available in large quantities, and in Indonesia solar energy has an intensity of between $0.6-0.7 \mathrm{~kW} / \mathrm{m}^{2}$. These research used an experimental modelas a method. Primary data obtained from the field, Ujung Kulon and Palabuhanratu, then analyzed to find out how much electricity the fishing vessel actually needs. From the results of the experiments, it was found that the power generated by the solar panels at the first research location in Ujung Kulon for 2 days was $0.672 \mathrm{kWh}$, an average of charging for 7 hours 15 minutes per day, at the second location in Palabuhan Ratu for 2 days is $0.672 \mathrm{kWh}$ with an average charge of 6 hours 30 minutes per day. Potential PLTS on fishing vessels with a capacity of 30 GT has the potential to lay solar panels as many as 24 units with a capacity of $250 \mathrm{Wp}$ with a total power of $25.65 \mathrm{kWh} /$ day unable to fulfill the needs of this $30 \mathrm{GT}$ Fishing Vessel as large as $40.12 \mathrm{kWh} /$ day while for fishing vessels with a capacity of $10 \mathrm{GT}$ have The potential for solar energy with a power of $9.84 \mathrm{kWh} /$ day can fulfill the electricity needs that only $0.48 \mathrm{kWh} /$ day.
\end{abstract}

Keywords: solar energy, fishing vessels, solar panels, solar power plants

\section{ABSTRAK}

Salah satu upaya untuk mengatasi krisis energi adalah dengan mengurangi ketergantungan terhadap sumber energi fosil dengan memanfaatkan sumber energi alternatif yang salah satunya adalah energi surya. Upaya pemanfaatan energi surya di Indonesia memiliki keuntungan yaitu, energi tersedia dalam jumlah besar, dan energi surya mempunyai intensitas antara $0,6-0,7 \mathrm{~kW} / \mathrm{m}^{2}$. Metode penelitian yang dilakukan adalah dengan memakai model percobaan. Data primer didapat dari lapangan yaitu di daerah Ujung Kulon dan pantai Palabuhanratu kemudian dianalisis untuk mendapatkan berapa kebutuhan listrik kapal penangkap ikan yang sebenarnya. Dari hasil percobaan yang dilakukan didapatkan daya yang dihasilkan oleh panel surya pada tempat penelitian lokasi pertama di Ujung Kulon selama 2 hari sebesar 0,672 kWh rata-rata pengisian selama 7 jam 15 menit per hari, Pada lokasi kedua di Palabuhan ratu selama 2 hari sebesar 0,672 kWh dengan rata-rata pengisian selama 6 jam 30 menit per hari. Potensi PLTS pada kapal penangkap ikan kapasitas 30 GT memiliki potensi peletakan panel surya sebanyak 24 buah berkapasitas $250 \mathrm{Wp}$ dengan total daya sebesar 25,65 kWh/hari belum bisa memenuhi kebutuhan listrik sebebesar 40,12 kWh/hari sedangkan untuk kapal ikan berkapasitas 10 GT memiliki potensi energi surya dengan daya 9,84 $\mathrm{kWh} /$ hari dapat memenuhi kebutuhan listrik yang hanya sebesar 0,48 kWh/hari.

Kata kunci: energi surya, kapal penangkap ikan, panel surya, Pembangkit Listrik Tenaga Surya (PLTS). 


\section{PENDAHULUAN}

Energi matahari merupakan salah satu sumber energi terbarukan yang dapat menjawab kebutuhan energi alternatif. Kondisi geografis yang dimiliki Indonesia yang merupakan Negara Kepulauan yang memiliki daerah garis pantai yang panjang dan lautan yang luas merupakan sebuah nilai lebih untuk pemanfaatan energi matahari.

Ujung kulon dan Palabuhanratu merupakan salah satu pantai yang letaknya berada di selatan pulau jawa, di pilihnya kedua lokasi tersebut dikarenakan potensi perikanannya sangat besar (Dinas Perikanan Kabupaten Pandeglang 2017) dan banyak dari masyarakat daerah sekitar pantai berprofesi sebagai nelayan. Pada saat sekarang ini nelayan kerap dihadapkan pada besarnya pengeluaran saat melaut. Masyarakat nelayan tradisional umumnya menggunakan solar untuk mesin perahu atau kapal, serta minyak tanah untuk bahan bakar lampu petromaks. Permasalahan dicabutnya subsidi minyak tanah akan menjadikan permasalahan besar bagi nelayan di Indonesia, karena seluruh kegiatanya mengunakan minyak bumi, seperti untuk menangkap ikan di laut nelayan mengandalkan cahaya yang dihasilkan oleh mesin bantu atau genset dengan berbahan bakar solar.

Salah satu energi alternatif yang perlu dikembangkan di Indonesia yaitu energi surya. Energi surya di Indonesia mempunyai intensitas antara $0,6-0,7 \mathrm{~kW} / \mathrm{m}^{2}$ (Manan 2009). Bagi Indonesia, upaya pemanfaatan energi surya memiliki beberapa keuntungan yaitu, energi tersedia dalam jumlah besar, dan Indonesia merupakan daerah tropis yang dimana mendapatkan ratarata sinar matahari 6 jam dalam sehari dengan cuaca yang sangat mendukung.

Perkembangan penelitian dalam penggunaan solar panel pada kapal penangkap ikan atau kapal laut antara lain yaitu perencanaan sistem pembangkit listrik Hybrid (Sel Surya dan Diesel Generator) pada Kapal Tanker (Putri et al. 2016) yang hasilnya menyatakan bahwa penggunaan sistem pembangkit listrik hybrid sangat prospektif untuk diterapkan di kapal-kapal. Hal ini dikarenakan Lifetime kapal mencapai 20 tahun, sedangkan BEP terjadi kurang dari 4 tahun. Sedangkan Syahbana (2012) telah melakukan percobaan dengan pemanfaatan energi surya sebagai tenaga alternatif sistem kelistrikan lampu navigasi pada kapal penagkap ikan dengan menggunakan panel surya berukuran $30 \mathrm{Wp}$.

Konsumsi pemakaian bahan bakar minyak di bidang perkapalan cukup besar terutama sebagai sumber energi listrik dan bahan bakar untuk menggerakkan kapal. Tingginya harga bahan bakar minyak sama sekali tidak menguntungkan industri pelayaran dan nelayan sebagai pengguna kapal bermotor, sehingga energi matahari/surya dapat digunakan sebagai energi alternatif pengganti Bahan Bakar/Solar yang perlu dikembangkan di Indonesia.

\section{METODE}

Metode penelitian yang digunakan dalam penelitian ini adalah metode percobaan dan analisis, yaitu melakukan uji coba dan menganalisa berapa neregi potensial dari panel surya sebagai tenaga alternatif pada kapal penangkap ikan. Dalam penelitian ini dilakukan analisis untuk menghitung energy tersebut .

Penelitian akan dilaksanakan dalam dua tahap, tahap pertama yaitu persiapan alat yang dilaksanakan pada bulan Oktober-Desember 2017 di Lap Uji Material Universitas Darma Persada, tahap kedua yaitu pengujian alat dan pengambilan data yang dilaksanakan pada bulan Januari-Maret 2018 di Pantai selatan Jawa Barat Khususnya di Taman Nasional Ujung Kulon dan di Pelabuhan Ratu dilaksanakan pada bulan April-Juli 2018.

\section{HASIL DAN PEMBAHASAN}

\section{Wilayah Percobaan 1 : Ujung Kulon}

1) Intensitas Cahaya terhadap Tegangan Baterai

Hari Pertama 
Berdasarkan Kurva 1 dapat dilihat intensitas cahaya matahari mengalami peningkatan yang tidak terlalu signifikan atau cenderung naik dan turun, namun pada pukul 13.30 WIB intensitas cahaya matahari mengalami penurunan sebesar 30.500 Lux.

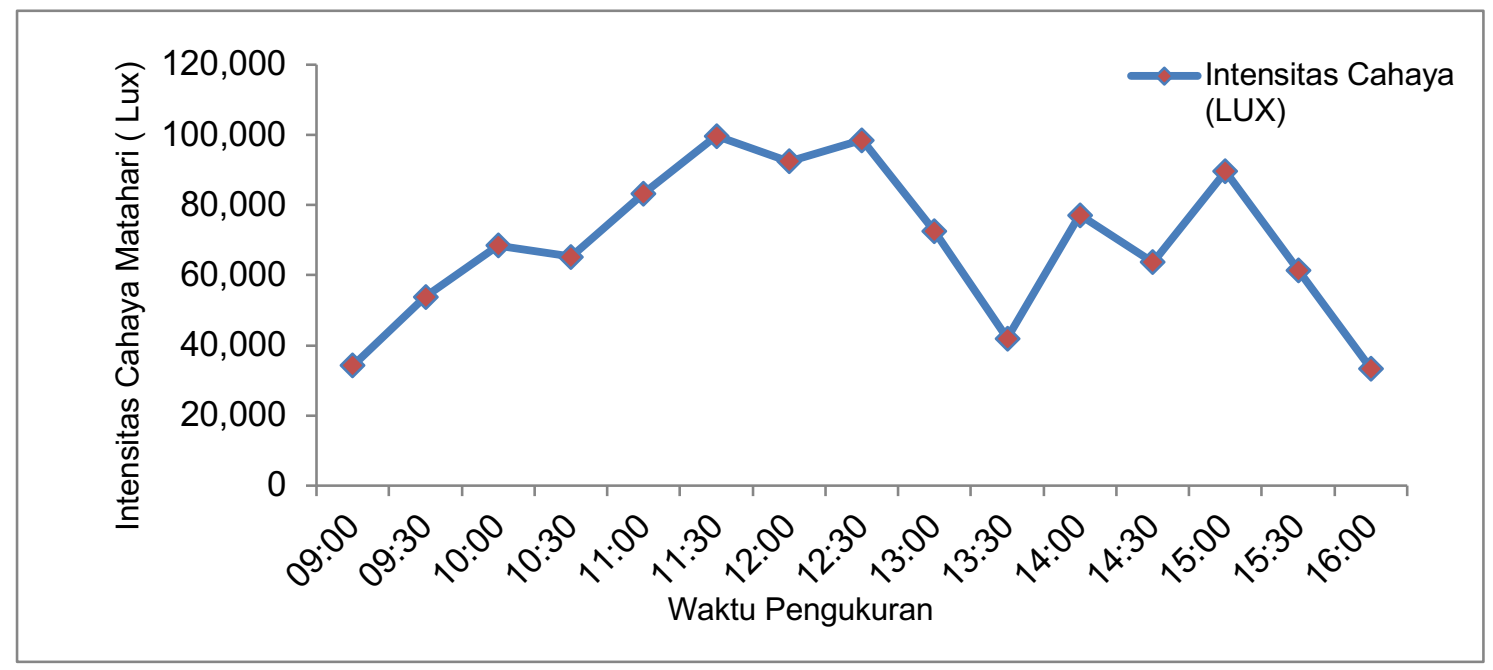

Gambar 1 Kurva intensitas cahaya matahari pada hari pertama

Nilai rata-rata intensitas cahaya matahari yang didapat pada saat penelitian cukup rendah ialah sebesar 69.033 Lux, dikarenakan keadaan cuaca di lokasi tempat penelitian sedang berawan. Intensitas cahaya matahari terbesar didapat pada pukul 11.30 WIB dengan nilai sebesar 99.700 Lux. Adapun nilai intensitas cahaya matahari terendah didapat pada pukul 16.00 WIB sebesar 33.400 Lux.

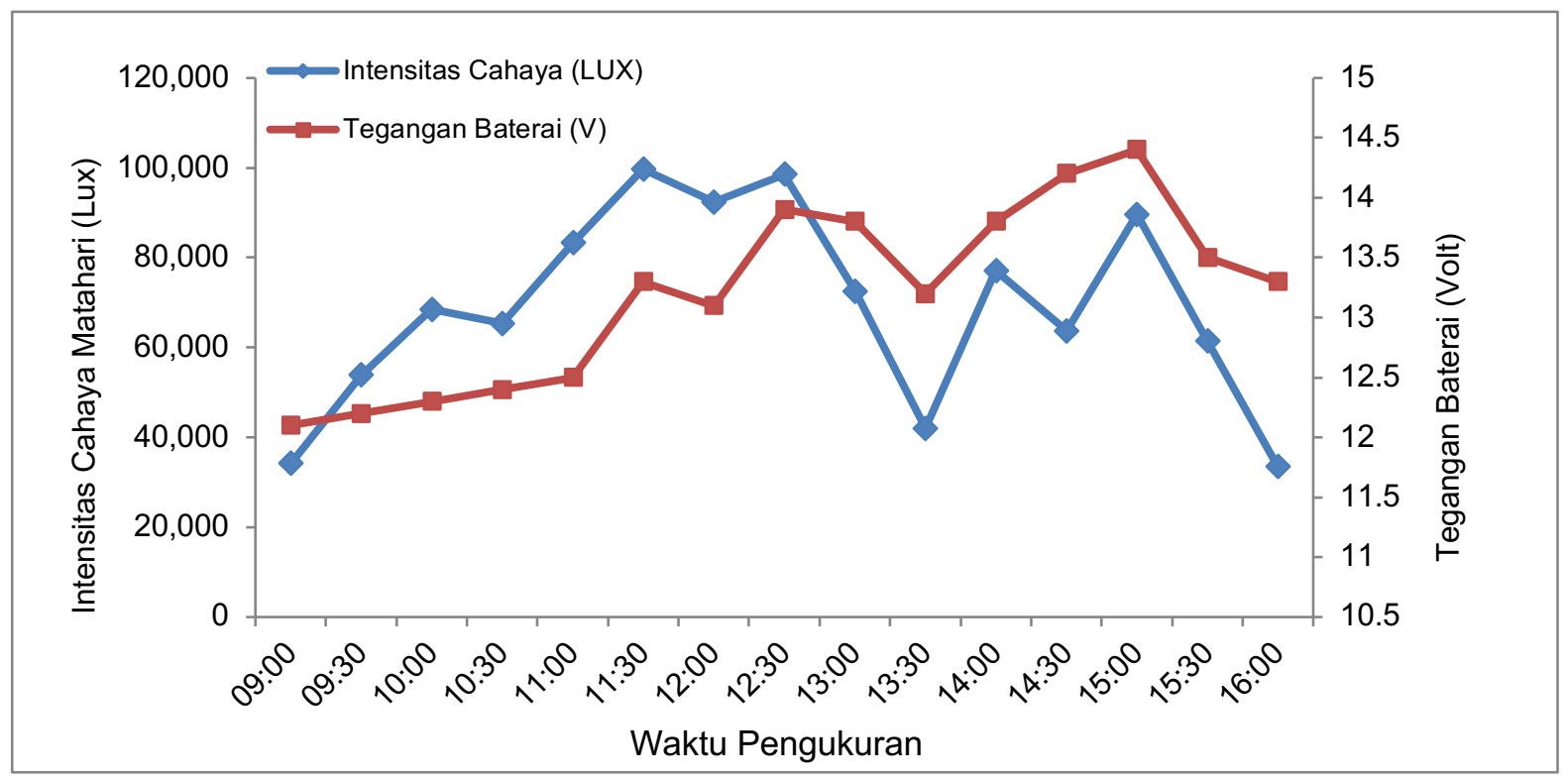

Gambar 2 Kurva pengaruh intensitas cahaya terhadap tegangan baterai

Berdasarkan Kurva pada gambar diatas tegangan terbesar terjadi pada pukul 15:00 WIB sebesar $14,4 \mathrm{~V}$ dengan intensitas cahaya matahari yang di terima sebesar 89.600 Lux. Adapun tegangan terendah yang didapat pada pukul 09:00 WIB sebesar $12.1 \mathrm{~V}$ dengan intensitas cahaya matahari yang di terima sebesar 34,200 Lux.

Hari Kedua

Bentuk kurva seperti ditunjukan pada Gambar 3 menunjukkan intensitas cahaya matahari mengalami peningkatan pada puku 12.30 WIB sebesar 48,200 Lux. Nilai rata - rata intensitas 
cahaya matahari yang didapat pada saat penelitian cukup rendah ialah sebesar 73,52 Lux, dikarenakan keadaan cuaca di lokasi tempat penelitian sedang berawan. Intensitas cahaya matahari terbesar didapat pada pukul 14.00 WIB dengan nilai sebesar 104.800 Lux. Adapun nilai intensitas cahaya matahari terendah didapat pada pukul 16.00 WIB sebesar 48.800 Lux.

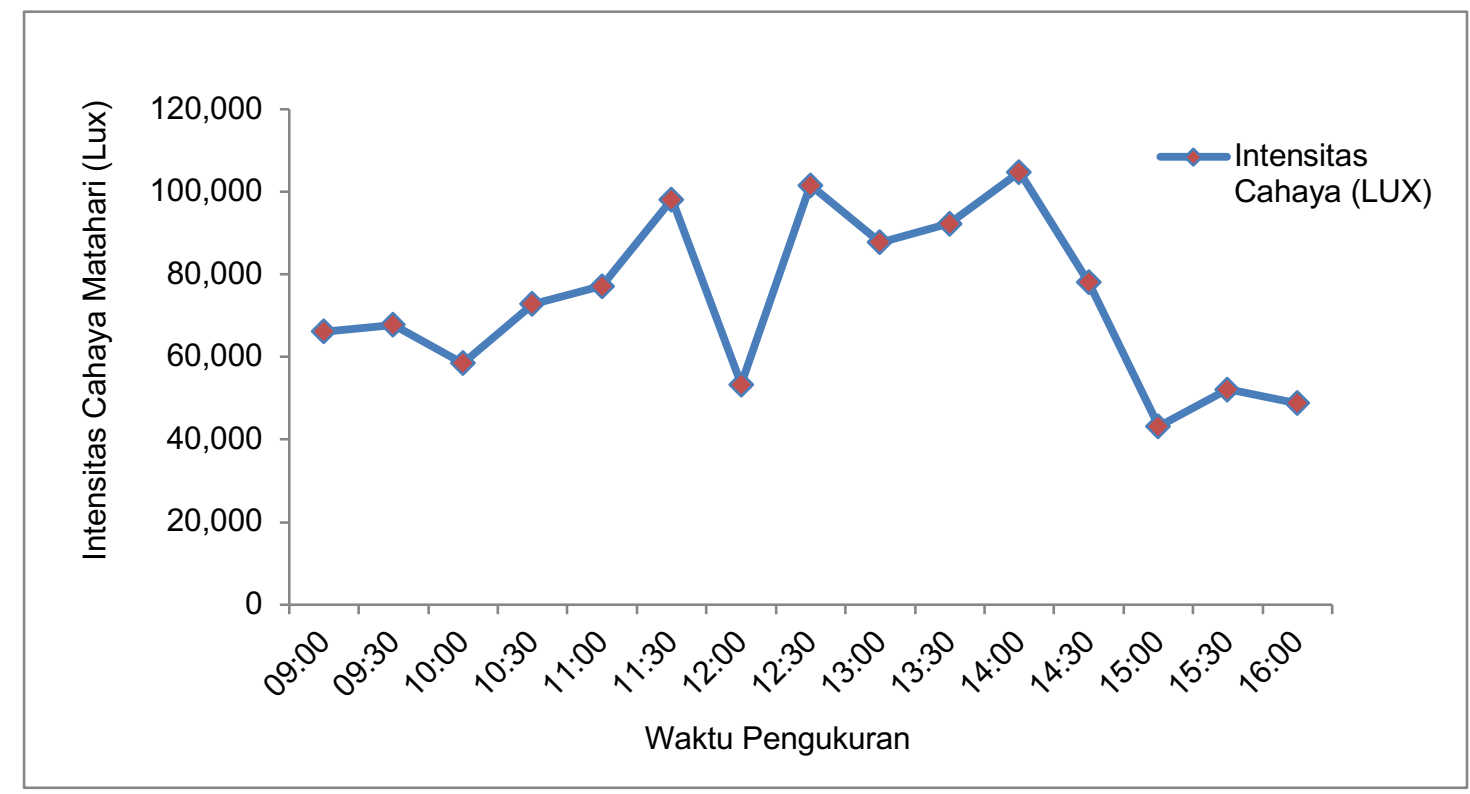

Gambar 3 Kurva intensitas cahaya matahari hari kedua

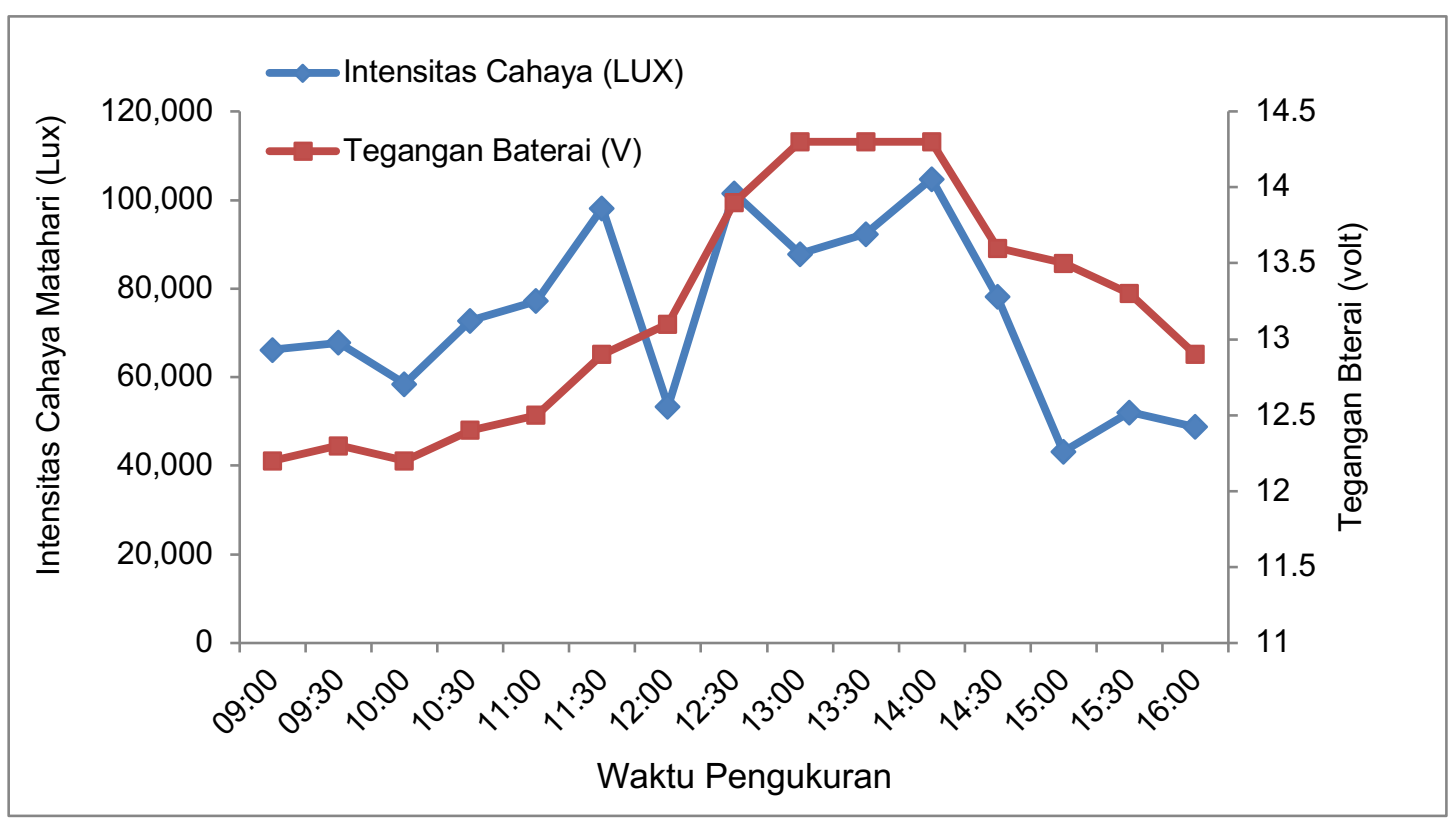

Gambar 4 Kurva pengaruh intensitas cahaya terhadap tegangan baterai

Berdasarkan kurva pada gambar diatas tegangan terbesar terjadi pada pukul 13:00, 13:30 dan 14:00 WIB sebesar 14,3 V dengan rata-rata intensitas cahaya matahari yang di terima sebesar 94,967 Lux. Adapun tegangan terendah yang didapat pada pukul 09:00 dan 10:00 WIB sebesar $12.2 \mathrm{~V}$ dengan rata-rata intensitas cahaya matahari yang di terima sebesar 62.350 Lux.

2) Pengaruh Intensitas Cahaya Terhadap Tegangan Solar Panel

\section{Hari Pertama}

Bentuk kurva Pengaruh Intensitas Cahaya Matahari Terhadap Tegangan Solar Panel ditunjukan pada Gambar 5. 


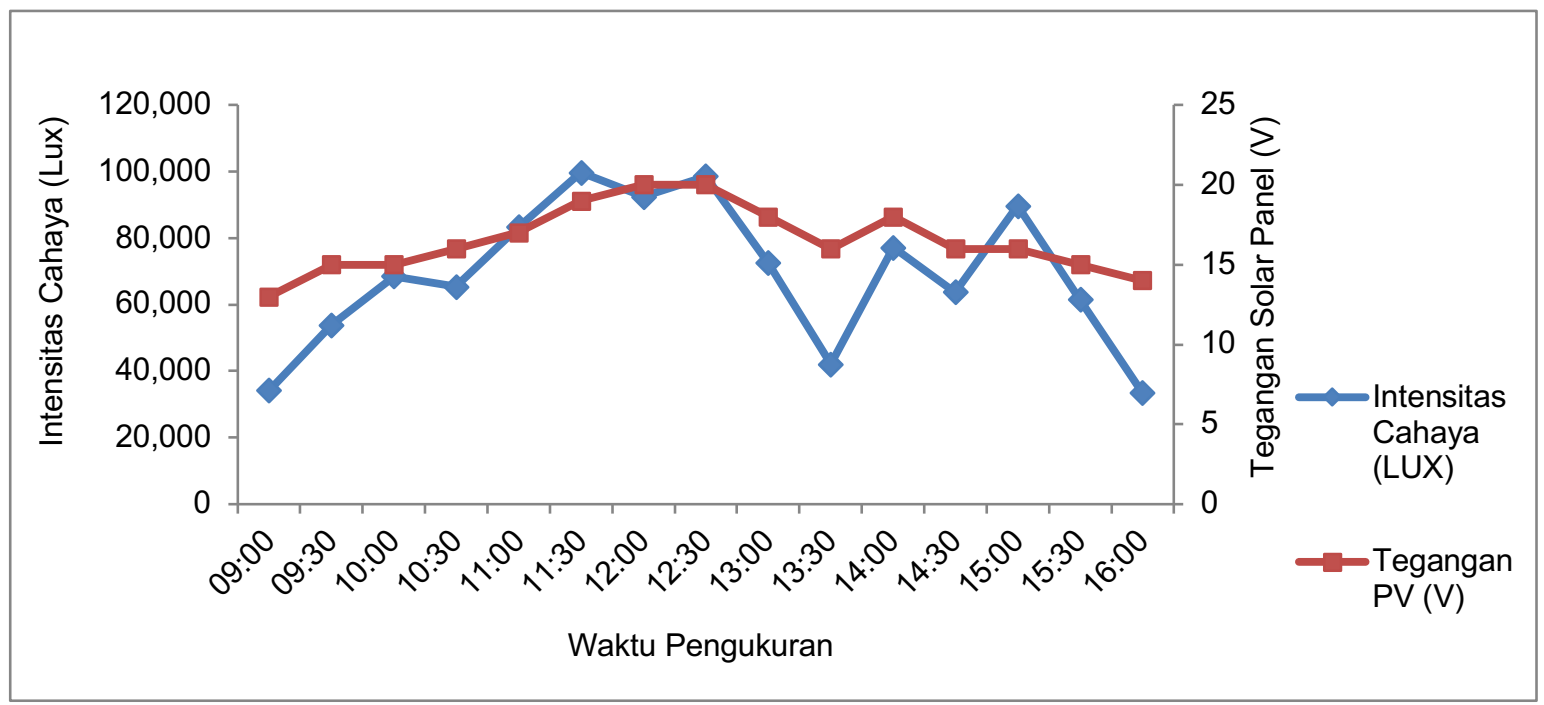

Gambar 5 Kurva pengaruh intensitas cahaya matahari terhadap tegangan solar panel

Berdasarkan kurva pada gambar diatas tegangan terbesar terjadi pada pukul 12:00 dan 12:30 WIB sebesar $20 \mathrm{~V}$ dengan rata-rata intensitas cahaya matahari yang di terima sebesar 95.450 Lux. Adapun tegangan terendah yang didapat pada pukul 09:00 WIB sebesar $13 \mathrm{~V}$ dengan intensitas cahaya matahari yang di terima sebesar 34.200 Lux. Nilai rata-rata tegangan solar panel yang didapat dari pukul 09:00 hingga pukul 16:00 WIB sebesar 16,53 V.

Hari Kedua

Berdasarkan kurva pada Gambar 6, tegangan terbesar terjadi pada pukul 11:00,11:30 dan 12:30 WIB sebesar $20 \mathrm{~V}$ dengan rata-rata intensitas cahaya matahari yang di terima sebesar 92,333 Lux. Adapun tegangan terendah yang didapat pada pukul 09:00, 15:00 dan 16:00 WIB sebesar $14 \mathrm{~V}$ dengan intensitas cahaya matahari yang di terima sebesar 52,733 Lux. Nilai ratarata tegangan solar panel yang didapat dari pukul 09:00 hingga pukul 16:00 WIB sebesar 16,67 V.

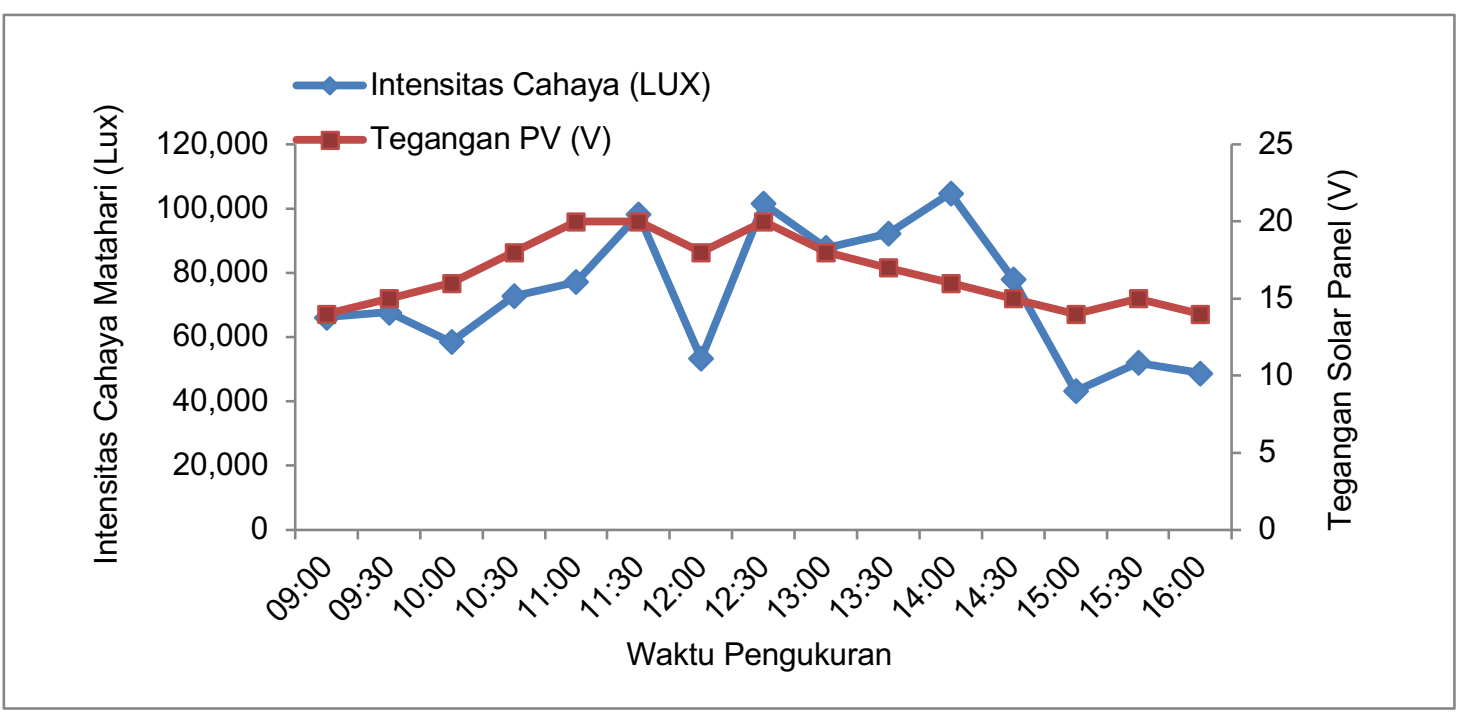

Gambar 6 Kurva pengaruh intensitas cahaya matahari terhadap tegangan solar panel

\section{Wilayah Percobaan 2 : Palabuhanratu}

1) Intensitas Cahaya terhadap Tegangan Baterai 


\section{Hari Pertama}

Berdasarkan Kurva dibawah ini dapat dilihat intensitas cahaya matahari mengalami peningkatan yang tidak terlalu signifikan dan cenderung stabil atau merata. Nilai rata-rata intensitas cahaya matahari yang didapat pada saat penelitian cukup tinggi ialah sebesar 88.580 Lux, dikarenakan keadaan cuaca di lokasi tempat penelitian sedang cerah. Intensitas cahaya matahari terbesar didapat pada pukul 12.30 WIB dengan nilai sebesar 103,100 Lux. Adapun nilai intensitas cahaya matahari terendah didapat pada pukul 09.00 WIB sebesar 74.200 Lux.

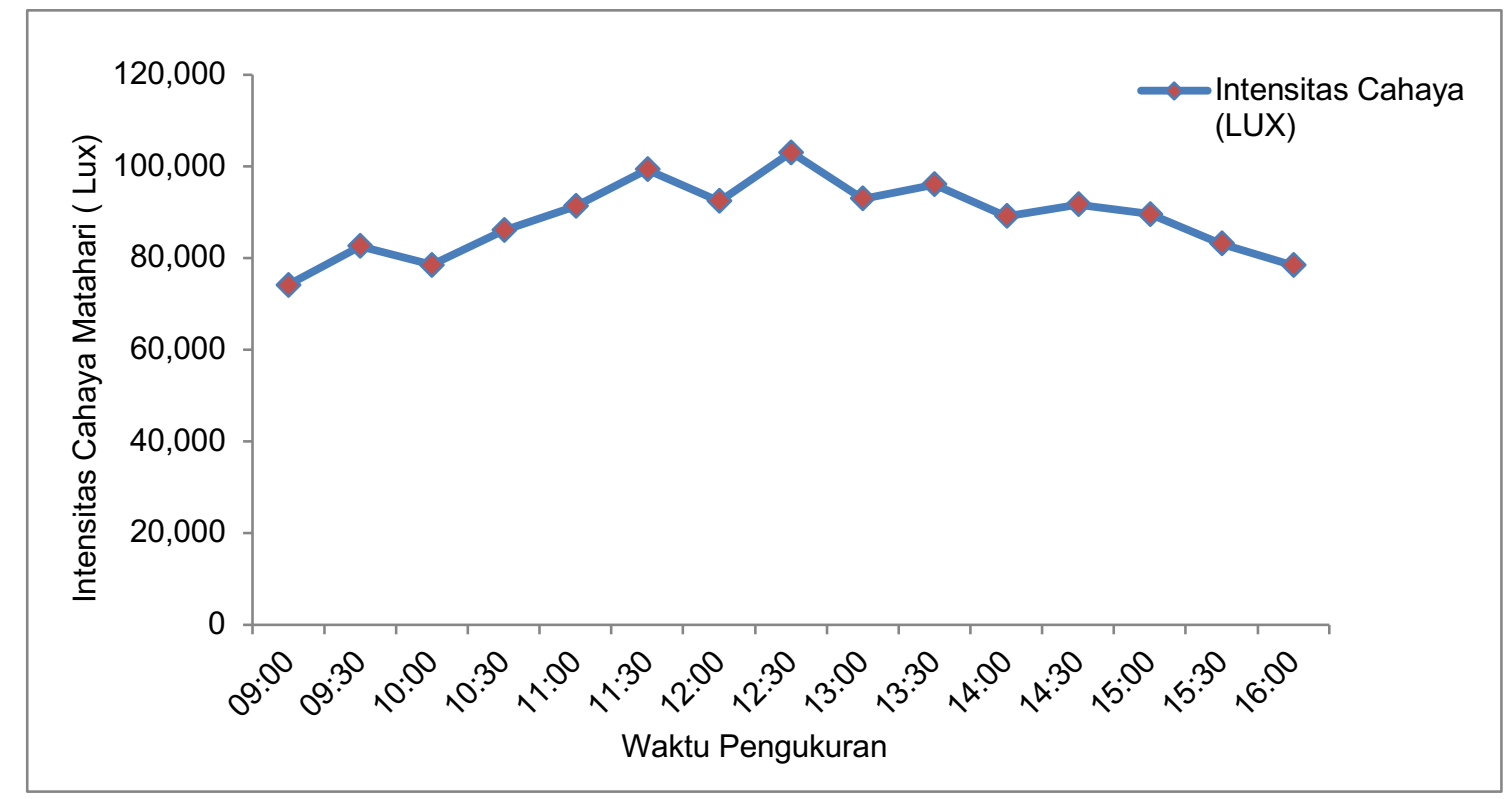

Gambar 7 Kurva intensitas cahaya matahari pada hari pertama

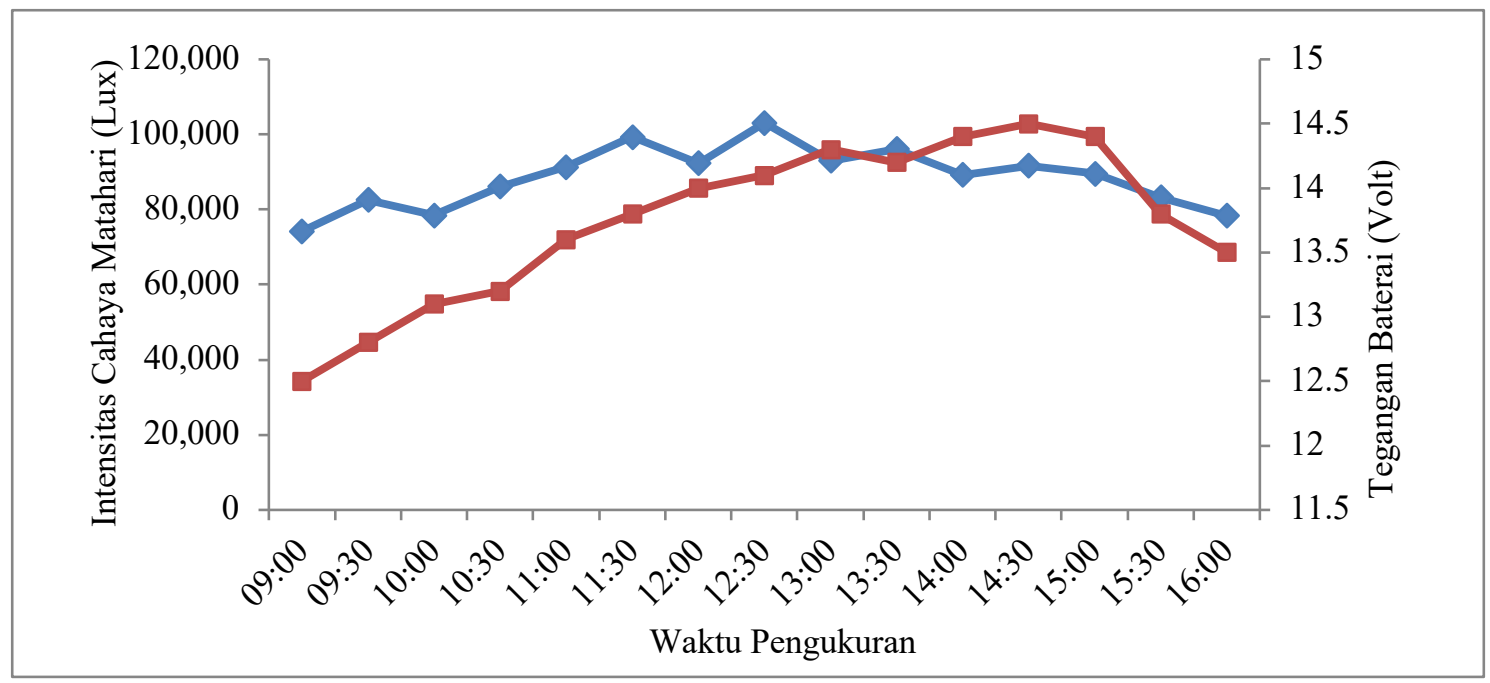

Gambar 8 Kurva pengaruh intensitas cahaya terhadap tegangan baterai

Berdasarkan Kurva pada gambar diatas tegangan terbesar terjadi pada pukul 14:30 WIB sebesar 14,5 V dengan intensitas cahaya matahari yang di terima sebesar 91.700 Lux. Adapun tegangan terendah yang didapat pada pukul 09:00 WIB sebesar $12.5 \mathrm{~V}$ dengan intensitas cahaya matahari yang di terima sebesar 74.200 Lux.

Hari Kedua

Berdasarkan Gambar 8 dapat dilihat intensitas cahaya matahari mengalami peningkatan pada puku 12.30 WIB sebesar 101.600 Lux. Nilai rata-rata intensitas cahaya matahari yang didapat pada saat penelitian cukup rendah ialah sebesar 73,52 Lux, dikarenakan keadaan cuaca 
di lokasi tempat penelitian sedang berawan. Intensitas cahaya matahari terbesar didapat pada pukul 14.00 WIB dengan nilai sebesar 104.800 Lux. Adapun nilai intensitas cahaya matahari terendah didapat pada pukul $16.00 \mathrm{WIB}$ sebesar 48.800 Lux.

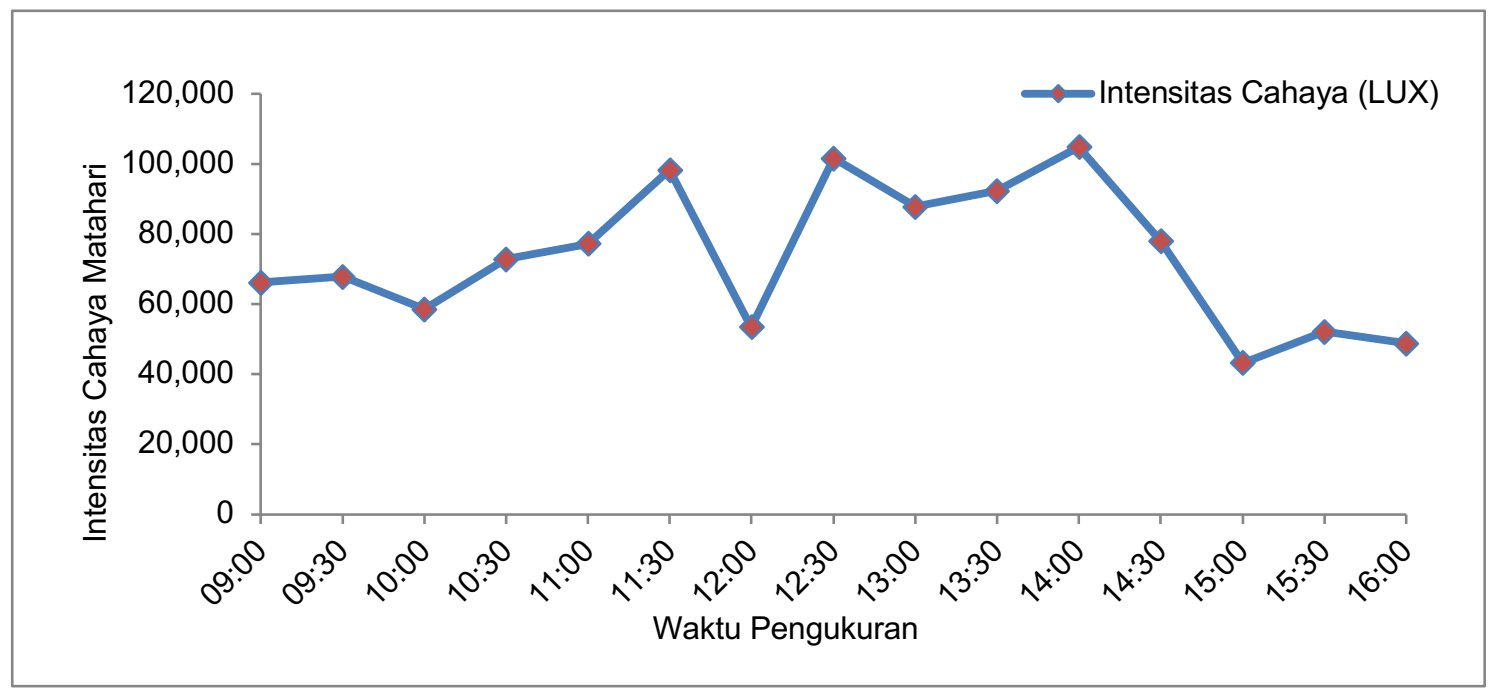

Gambar 9 Kurva intensitas cahaya

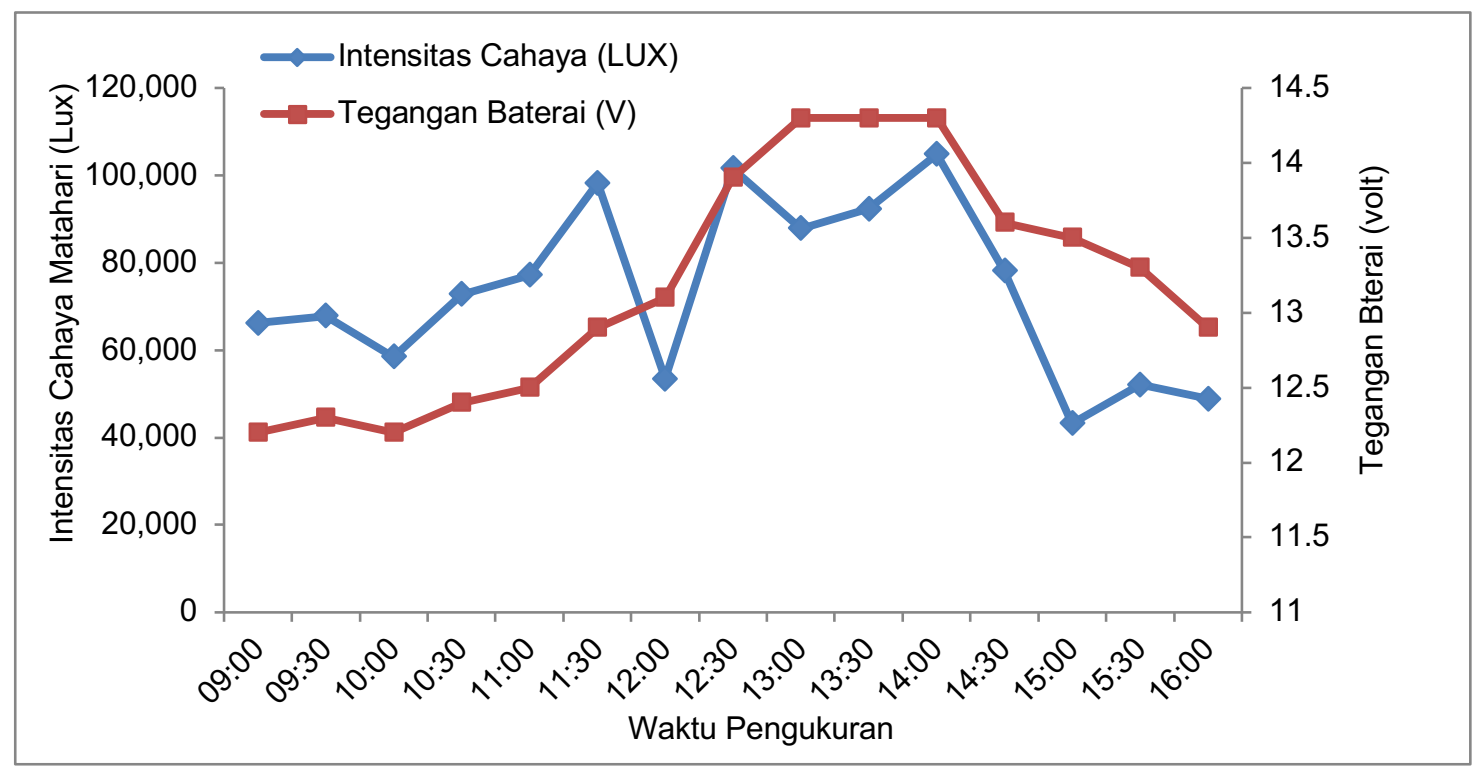

Gambar 10 Kurva pengaruh intensitas cahaya terhadap tegangan baterai

Berdasarkan kurva pada gambar diatas tegangan terbesar terjadi pada pukul 13:00, 13:30 dan 14:00 WIB sebesar 14,3 V dengan rata-rata intensitas cahaya matahari yang di terima sebesar 94.967 Lux. Adapun tegangan terendah yang didapat pada pukul 09:00 dan 10:00 WIB sebesar 12.2 V dengan rata-rata intensitas cahaya matahari yang di terima sebesar $62.350 \mathrm{Lux}$.

2) Pengaruh Intensitas Cahaya Terhadap Tegangan Solar Panel

\section{Hari Pertama}

Berdasarkan kurva pada gambar dibawah tegangan terbesar terjadi pada pukul 12:00, 12:30 dan 13.00 WIB sebesar $20 \mathrm{~V}$ dengan rata-rata intensitas cahaya matahari yang di terima sebesar 96.167 Lux. Adapun tegangan terendah yang didapat pada pukul 09:00 WIB sebesar 15 $\checkmark$ dengan intensitas cahaya matahari yang di terima sebesar 74.200 Lux. Nilai rata-rata tegangan solar panel yang didapat dari pukul 09:00 hingga pukul 16:00 WIB sebesar 17,066 V. 


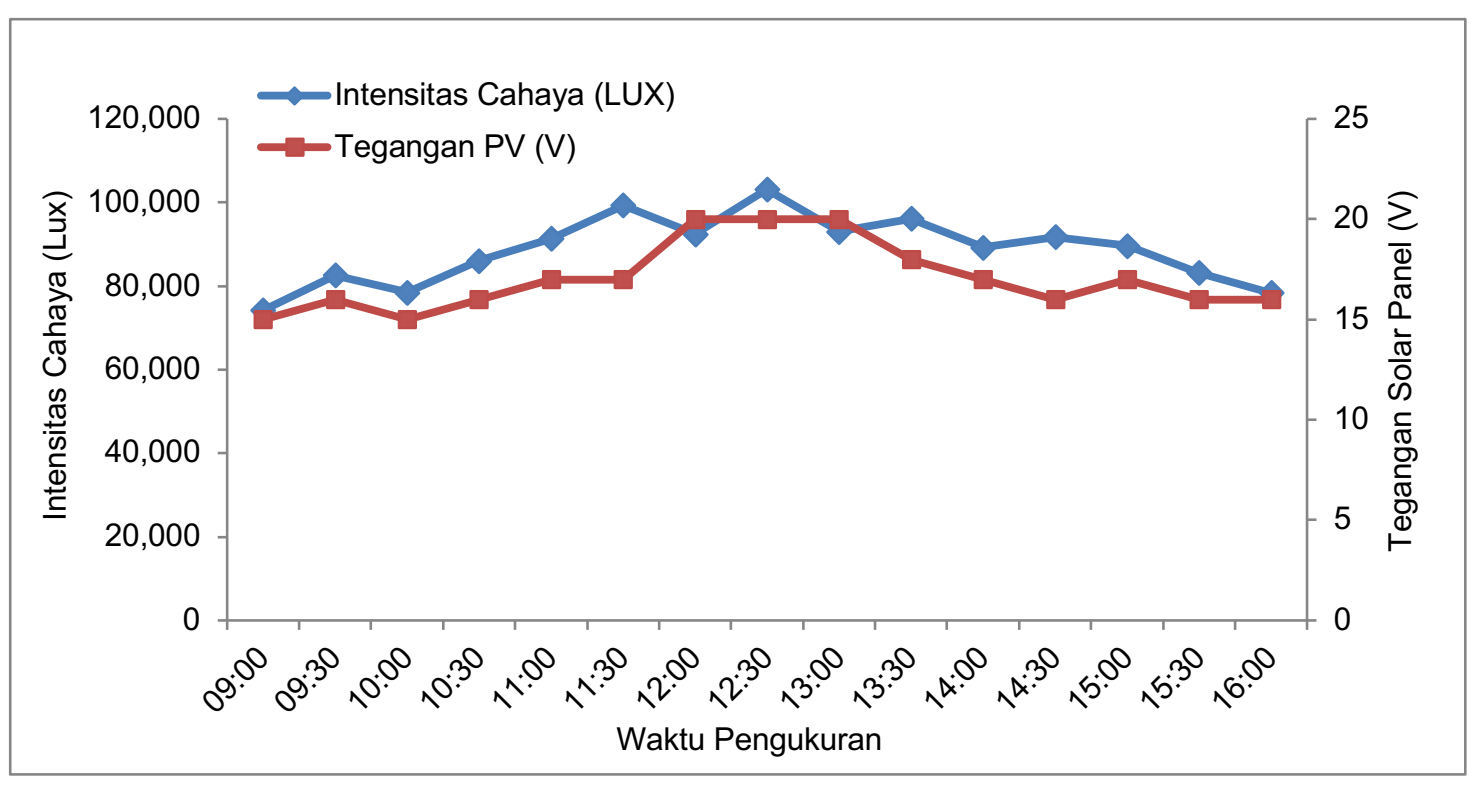

Gambar 11 Kurva pengaruh intensitas cahaya terhadap tegangan solar panel

Hari Kedua

Berdasarkan kurva pada Gambar 12 tegangan terbesar terjadi pada pukul 13.00 WIB sebesar $20 \mathrm{~V}$ dengan intensitas cahaya matahari yang di terima sebesar 98.800 Lux. Adapun tegangan terendah yang didapat pada pukul $09.00 \mathrm{WIB}$ sebesar $14 \mathrm{~V}$ dengan intensitas cahaya matahari yang di terima sebesar 73.100 Lux. Nilai rata-rata tegangan solar panel yang didapat dari pukul 09:00 hingga pukul 16:00 WIB sebesar 16,6 V.

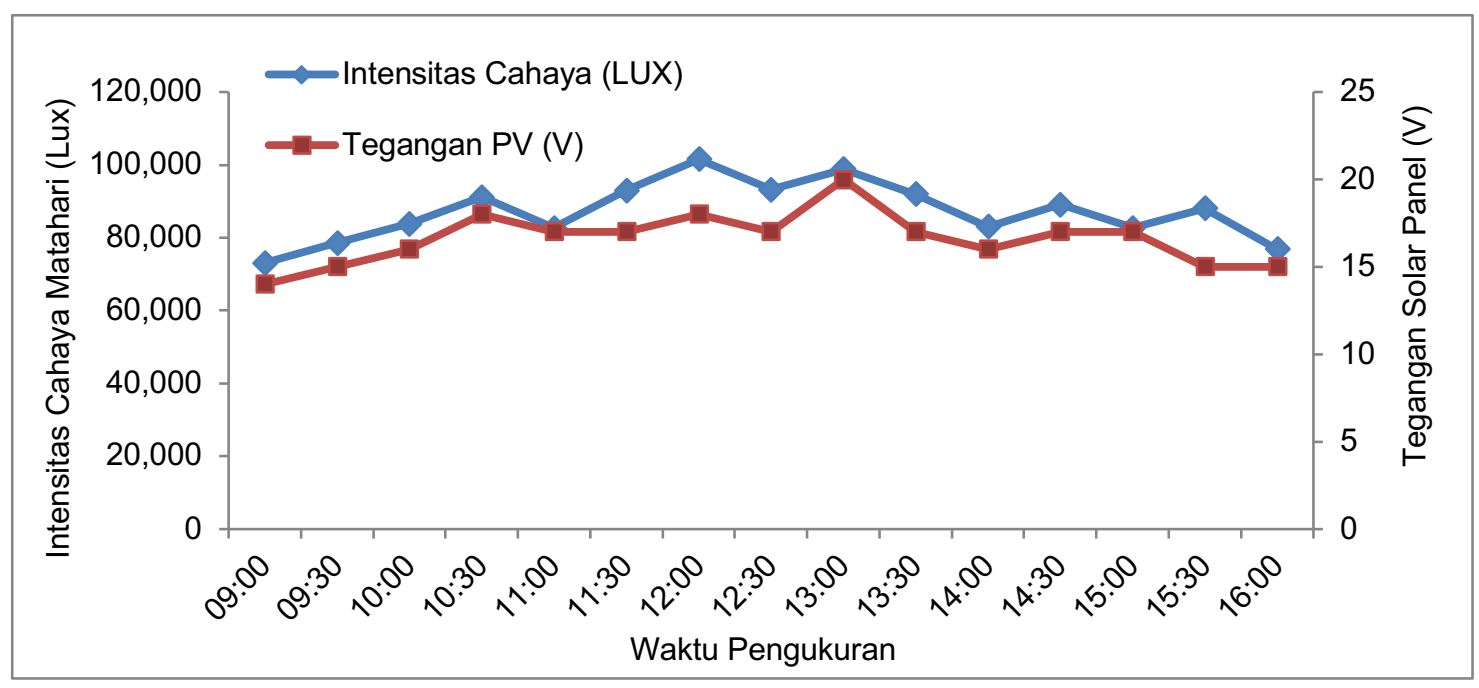

Gambar 12 Kurva pengaruh intensitas cahaya matahari terhadap tegangan solar panel

\section{SIMPULAN}

Percobaan yang dilakukan di Ujung Kulon, hari pertama, nilai rata-rata tegangan solar panel yang didapat dari pukul 09:00 hingga pukul 16:00 WIB sebesar 16,53 V, sedangkan pada hari kedua nilai didapat sebesar $16,67 \mathrm{~V}$. Sementara di Palabuhanratu pada hari pertama, nilai rata-rata tegangan solar panel yang didapat dari pukul 09:00 hingga pukul 16:00 WIB sebesar $17,066 \mathrm{~V}$, sedangkan pada hari ke dua didapat sebesar 16,6 V. Daya yang dihasilkan oleh panel surya untuk tempat penelitian lokasi pertama di ujung kulon selama 2 hari sebesar $0,672 \mathrm{kWh}$ rata-rata pengisian baterai dapat dilakukan selama 7 jam 15 menit per hari,sedangkan di lokasi 
kedua penelitian di Sukabumi selama 2 hari sebesar $0,672 \mathrm{kWh}$ dengan rata-rata pengisian selama 6 jam 30 menit per hari.

\section{UCAPAN TERIMA KASIH}

Terimakasih kepada LP2MK Universitas darma Persada yang telah mendanai penelitian ini.

\section{DAFTAR PUSTAKA}

Putri DP, Koenhardono ES, Kusuma IR. (2016). Perencanaan Sistem Pembangkit Listrik Hybrid (Sel Surya dan Diesel Generator) pada Kapal Tanker. Jurnal Teknik ITS, 5(2): 394-399.

Dinas Perikanan Pandeglang Banten. (2017). dinasperikanan. pandeglangkab.co.id.

Manan S. (2009). Energi matahari, sumber energi alternatif yang effisien, handal, dan ramah lingkungan di indonesia. Karya Tulis. Semarang (ID): Program Diploma II Teknik Elektro, Universitas Diponegoro.

Syahbana RA. (2012). Percobaan pendahuluan pemanfaatan energi surya sebagai energi alternatif sistem kelistrikan lampu navigasi pada kapal penangkap ikan. Skripsi. Bogor (ID): Fakultas Perikanan dan IImu Kelautan Institut Pertanian Bogor. 